\title{
Perencanaan Jaringan Perpipaan Kawasan Tumbuh Kembang Perumahan Desa Logandeng Kabupaten Gunungkidul Menggunakan Aplikasi Epanet 2.0
}

\author{
Tito Ghazy Aflah ${ }^{1}$, Sri Hastutiningrum ${ }^{2 *}$, Soedarsono ${ }^{3}$ \\ 1,2,3 Jurusan Teknik Lingkungan, Institut Sains \& Teknologi AKPRIND Yogyakarta \\ *Koresponden email : shningrum20@gmail.com
}

Diterima: 4 Januari 2022

Disetujui: 24 Januari 2022

\begin{abstract}
According to data from PDAM Tirta Handayani, Gunungkidul Regency, as the manager of clean water providers in Wonosari City and its surroundings, currently only able to serve about $76 \%$ of the total population in the service area, mostly through direct lines. Condition Currently, there are still many obstacles in drinking water services, especially in terms of distribution to customer. The purpose of the study was to determine the required discharge in housing and Knowledge of pipeline network planning. This research is located in the housing that will be built in Logandeng village, Gunungkidul district. Data were collected including debits, hours peak water use, and look at the topography of the planning area as an observation technique in data input, besides that, interview techniques are also used to be able to find out the number of houses and population in the housing planning area. Based on calculation analysis and epanet simulations in planning the clean water distribution network in housing that will be built in the village of Logandeng, in planning the distribution pipe network system using gravity drainage system, the highest elevation here is 206 MDPL and the lowest is 188 MDPL, so that the debits in the planning system still reach planning with branch system. Water demand in Logandeng housing in 2021 is $0.921 \mathrm{~L} / \mathrm{second}$ with a population of 511 people, while in 2025 it is $1.188 \mathrm{~L} /$ second with population of 664 people.
\end{abstract}

Keywords: discharge, drinking water, housing, PDAM, water distribution network, water supply

\begin{abstract}
Abstrak
Menurut data dari PDAM Tirta Handayani Kabupaten Gunungkidul, sebagai pengelola penyedia air bersih di Kota Wonosari dan sekitarnya, saat ini baru dapat melayani sekitar $76 \%$ dari jumlah penduduk di daerah pelayanan, sebagian besar melalui sambungan langsung. Kondisi pelayanan air minum saat ini masih banyak kendala terutama dalam hal pendistribusian ke pelanggan. Tujuan penelitian adalah mengetahui debit yang dibutuhkan di perumahan dan mengetahui perencanaan jaringan pipa. Penelitian berlokasi di perumahan yang akan dibangun di desa Logandeng, kabupaten Gunungkidul. Dilakukan pengambilan data diantaranya debit, jam puncak penggunaan air, dan melihat topografi daerah perencanaan sebagai teknik observasi dalam penginputan data, selain itu juga dilakukan wawancara untuk mengetahui jumlah rumah serta jumlah penduduk yang ada di daerah perencanaan perumahan. Berdasarkan analisa perhitungan dan simulasi epanet dalam perencanaan jaringan distribusi air bersih di perumahan yang akan dibangun di desa Logandeng, pada perencanaan sistem jaringan pipa distribusi menggunakan sistem pengaliran secara gravitasi, Elevasi tertinggi diperoleh sebesar 206 MDPL dan terendah sebesar 188 MDPL, sehingga debit dalam sistem perencanaan masih menjangkau perencanaan dengan sistem bercabang. Kebutuhan air di perumahan Logandeng pada tahun 2021 sebesar 0,921 L/detik dengan jumlah penduduk 511 jiwa, sedangkan pada tahun 2025 sebesar 1,188 L/detik dengan jumlah penduduk 664 jiwa.
\end{abstract}

Kata kunci: debit, air minum, perumahan, PDAM, jaringan distribusi air, penyediaan air

\section{Pendahuluan}

Air merupakan salah satu kebutuhan dasar yang sangat penting bagi kelangsungan hidup manusia. Tanpa air manusia tidak dapat bertahan hidup dan melaksanakan aktivitas sehari-hari. Kebutuhan air akan terus meningkat seiring dengan pertumbuhan manusia. Dimana pemanfaatannya tidak hanya terbatas untuk keperluan rumah tangga, tetapi juga untuk fasilitas umum, komersial dan sosial [1]. Manusia memerlukan air bersih yang harus memenuhi syarat kualitas yang cukup sesuai dengan standar kualitas air minum yang telah ditetapkan oleh Pemerintah Republik Indonesia melalui Departemen Kesehatan Republik Indonesia yang ditetapkan dengan peraturan menteri kesehatan No. 492 Tahun 2010. Air minum adalah air yang melalui proses pengolahan atau tanpa proses pengolahan yang memenuhi syarat kesehatan dan dapat langsung diminum. [11] 
Dalam usaha memenuhi kebutuhan akan air bersih, jaringan distribusi merupakan hal yang sangat penting. Karena jaringan distribusi inilah yang menyalurkan air dari instalasi pengolahan air menuju ke masyarakat. Sistem jaringan distribusi yang digunakan dapat menggunakan sistem jaringan perpipaan. Peran pemerintah sebagai perwakilan dari masyarakat wajib mengatur pemanfaatan dan penyediaan air untuk kebutuhan sehari-hari. Berdasarkan PP 122 Tahun 2015 tentang Sistem Penyediaan Air Minum menjelaskan bahwa penyediaan air untuk memenuhi kebutuhan hidup sehari-hari masyarakat yang digunakan untuk keperluan minum, masak, mandi, cuci, peturasan, dan ibadah masuk kedalam kegiatan penyediaan air minum.[12]

Secara umum penyediaan air minum terdiri dari unit produksi dan unit distribusi. Unit distribusi diarahkan menggunakan sistem tertutup atau perpipaan supaya tidak terjadi kontaminasi pada air yang didistribusikan [6]. Tujuan utama dari distribusi air minum adalah untuk mengalirkan air yang berasal dari unit pengolahan air kepada konsumen dengan kuantitas, kualitas, dan tekanan yang cukup. Di dalam proses selama distribusi air minum kondisi air minum dapat saja mengalami penurunan kualitas akibat reaksi antara air dengan jaringan air ataupun adanya intrusi air tanah ke dalam jaringan distribusi [6]. Selain itu fungsi pokok dari jaringan pipa distribusi adalah untuk mengalirkan air bersih ke seluruh pelanggan dengan tetap memperhatikan faktor kualitas, dan kontinuitas, serta tekanan air. Sistem distribusi air minum sangat di mungkinkan terjadi perubahan kualitas air terutama dari sisi biologi. Penjaminan kualitas air minum dari sisi biologi (dinyatakan bebas bakteri) dipenuhi dengan konsentrasi khlor minimal sebesar $0,2 \mathrm{mg} / \mathrm{L}$ dengan batas maksimum konsentrasi pembubuhan pada tandon sebesar $1 \mathrm{mg} / \mathrm{L}[8]$.

Karena mengingat akan pentingnya air bersih ini maka dari itu sangat penting jika air bersih mendapatkan prioritas penanganan utama karena menyangkut kehidupan orang banyak. Penanganan akan pemenuhan kebutuhan air bersih dapat dilakukan dengan berbagai cara, disesuaikan dengan sarana dan prasarana yang ada. Di daerah perkotaan, sistem penyediaan air bersih dilakukan dengan sistem perpipaan dan non perpipaan. Sistem perpipaan dikelola oleh Perusahaan Daerah Air Minum (PDAM) dan sistem non perpipaan dikelola oleh masyarakat baik secara individu maupun kelompok.

Menurut data dari PDAM Tirta Handayani Kabupaten Gunungkidul, sebagai pengelola penyedia air bersih di Kota Wonosari dan sekitarnya, saat ini baru dapat melayani sekitar $76 \%$ dari jumlah penduduk di daerah pelayanan, sebagian besar melalui sambungan langsung dan selebihnya melalui fasilitas komersial, fasilitas umum dan hidran umum. Kondisi pelayanan air minum PDAM Tirta Handayani saat ini masih banyak kendala terutama dalam hal pendistribusian ke pelanggan. Masih banyak daerah yang dalam 1 hari nya hanya mendapat pelayanan air bersih beberapa jam saja. Sedangkan cakupan di kecamatan Playen sendiri 12,37\% dengan luas wilayah administrasi $105,25 \mathrm{~km} 2$, dengan total jumlah penduduk kecamatan Playen 56.388 pada Tahun 2016.

Perumahan ini sendiri rencana nya akan dibangun di jalan Siyono, desa Logandeng, kecamatan Playen, kabupaten Gunungkidul, rencana akan dibangun 254 unit rumah. Tujuan dilakukannya studi ini adalah untuk mengetahui debit yang dibutuhkan untuk memenuhi kebutuhan air bersih di perumahan dan mengetahui perencanaan jaringan pipa.[15]

\section{Metode Penelitian}

Penelitian ini dilakukan di Desa Logandeng, Kecamatan Playen Kabupaten Gunungkidul. Penelitian ini dilaksanakan dari mulai bulan November 2020 hingga Desember 2020. Pengumpulan data primer dengan interview langsung pihak perumahan dan pengambilan secara langsung di lapangan. Adapun data sekunder diambil melalui jurnal, buku serta penelitian terdahulu. Diagram alir tahapan penelitian dapat dilihat pada Gambar 1. 


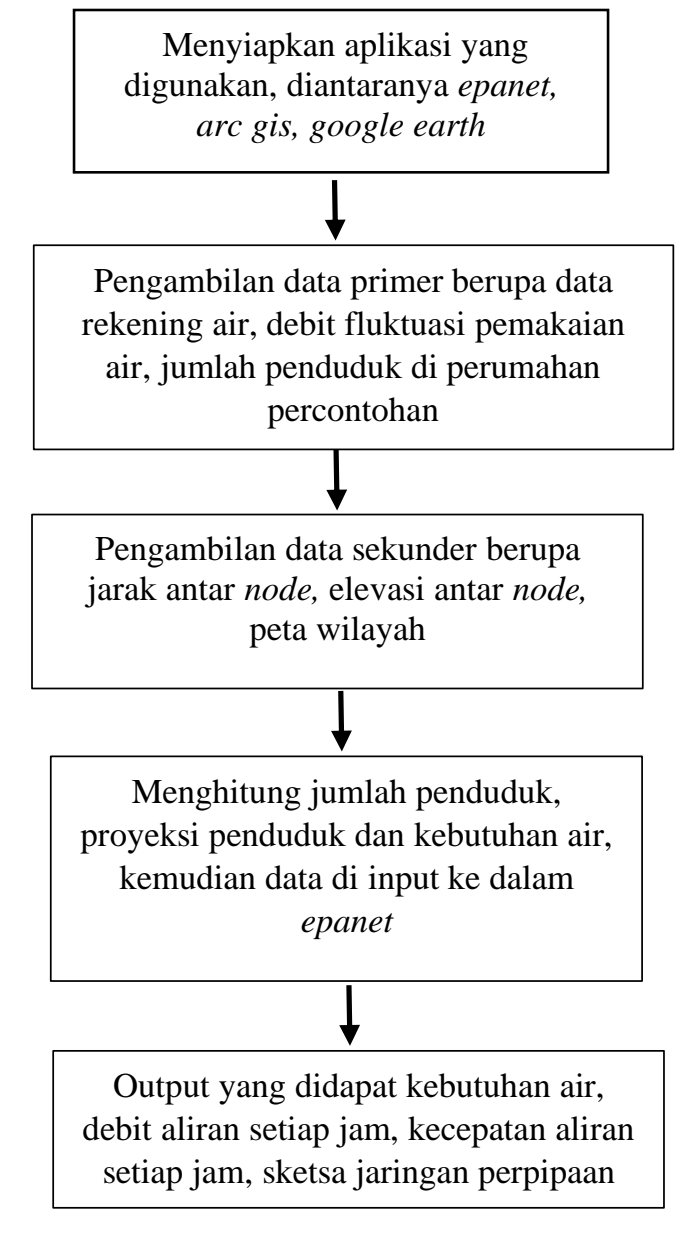

Gambar 1. Diagram alir penelitian

Sumber: Data penelitian, 2020

\section{Perhitungan jumlah penghuni}

Data jumlah penduduk digunakan untuk menghitung kebutuhan air di suatu daerah. Data jumlah penduduk di perumahan yang akan dibangun di Desa Logandeng, Kecamatan Playen, Kabupaten Gunungkidul, Yogyakarta ini diasumsikan dari rata-rata jumlah penghuni di 5 perumahan yang ada di Kabupaten Gunungkidul pada tahun pertama, kedua dan ketiga. Dari 5 perumahan tersebut semua rumah bersubsidi, dimana rumah bersubsidi di Gunungkidul mempunyai luas rumah berukuran $32 \mathrm{~m}^{2}$.

$$
\text { Jumlah Penduduk }=\frac{\text { Luas bangunan }}{\text { Kebutuhan ruang/orang }}
$$

Dimana menurut Keputusan Menteri Permukiman dan Prasarana Wilayah No. 403/KPTS/M/2002 kebutuhan ruang untuk 1 orang adalah 9 m2/orang.

Jumlah Penduduk $=\frac{32 m^{2}}{\frac{9 m^{2}}{\text { orang }}}=4$ jiwa $/$ rumah

\section{Perhitungan rata-rata jumlah penduduk}

Rata-rata penambahan jumlah penduduk ini diambil dari data pada tahun pertama, kedua dan ketiga warga yang tinggal pada 5 perumahan percontohan. Data diambil dari wawancara dengan ketua RT dan bagian pemasaran dari perumahan. Perhitungan data sebagai berikut:

Penduduk maks= total rumah $\times 4$ jiwa/rumah

$\mathrm{Jml}$ penduduk $=$ total jiwa pada tahun ke- $\mathrm{x}$ 
Persen jumlah penduduk $=\frac{\text { total jiwa pada tahun ke-x }}{\text { total jiwa maksimal }} \times 100 \%$

\section{Perhitungan proyeksi penduduk}

Proyeksi penduduk berfungsi untuk memperkirakan jumlah penduduk pada masa mendatang, sehingga didapatkan data kebutuhan air masa kedepan. Metode yang digunakan ada 3, sebelumnya dianalisa terlebih dahulu dengan melihat nilai korelasinya yang mendekati angka 1 [7]. Kemudian didapatkan metode yang paling tepat untuk memperkirakan proyeksi penduduk pada masa depan.

Metode yang dipakai diantaranya:

1. Least Square

$$
P n=a+b x
$$

Keterangan :

$\mathrm{Pn}=$ Jumlah penduduk tahun proyeksi

$\mathrm{a}, \mathrm{b}=$ Konstanta

$\mathrm{x}=$ Nomor tahun proyeksi (dihitung dari tahun awal data)

$\mathrm{X}=$ Jumlah tahun data

$\mathrm{Y}=$ Jumlah penduduk

$\mathrm{r}=$ Nilai korelasi

$\mathrm{n}=$ Jumlah data awal

2. Logaritmik

$$
\begin{array}{ll}
\text { Keterangan : } \\
\mathrm{Y} \quad=\text { Jumlah penduduk } \\
\mathrm{a}, \mathrm{b}=\text { Konstanta } \\
\mathrm{X} \quad=\text { Nomor tahun proyeksi (dihitung dari tahun awal data) } \\
\mathrm{X} \quad=\text { Jumlah tahun data } \\
\mathrm{ln} \quad=\text { Logaritma natural } \\
\mathrm{n} \quad=\text { Jumlah data awal } \\
\mathrm{r} & =\text { Nilai korelasi }
\end{array}
$$

3. Eksponensial

$$
\mathrm{Y}=a e^{b x}
$$

Keterangan :

$\mathrm{Y}=$ Jumlah penduduk

$\mathrm{a}, \mathrm{b}=$ Konstanta

$\mathrm{x}=$ Nomor tahun proyeksi (dihitung dari tahun awal data)

$\mathrm{X}=$ Jumlah tahun data

$e \quad=$ Bilangan eksponensial $(2,71828)$

$\ln =$ Logaritma natural

$\mathrm{n} \quad=$ Jumlah data awal

$\mathrm{r} \quad=$ Nilai korelasi

\section{Perhitungan flow factor \&Head factor}

Data pola pemakaian air merupakan data untuk aplikasi Epanet 2.0. Data tersebut diambil dari pola pemakaian air di perumahan Bhayangkara yang merupakan salah satu perumahan yang menjadi model dari perumahan yang akan dibangun di desa Logandeng. Perumahan Bhayangkara ini berada di kabupaten Gunungkidul.

Data pola pemakaian air berfungsi untuk mendapatkan nilai flow factor yang berfungsi untuk mengetahui jam puncak di dalam sistem jaringan distribusi

$$
\begin{aligned}
& \text { Flow factor }=\frac{\text { debit per jam }\left(\frac{\text { liter }}{\text { detik }}\right)}{\text { debit rata }-\operatorname{rata}\left(\frac{\text { liter }}{\text { detik }}\right)} \\
& \text { Head factor }=\frac{\text { Elevasi reservoir }+ \text { tekanan }}{\text { Elevasi reservoir }}
\end{aligned}
$$




\section{Jumlah Konsumen yang Terlayani}

Penentuan kebutuhan air liter/orang/hari diambil dari data rekening air pelanggan pada bulan sebelum penelitian, yaitu bulan November di perumahan Bhayangkara yang memiliki tingkat kebutuhan air hampir sama dengan daerah perencanaan.

a. Kebutuhan air

\section{b. Demand multiplier}

$$
\text { Kebutuhan air }=\frac{\text { Jumlah pemakaian air }}{\text { Jumlah SR }}
$$

\section{c. Demand real}

$$
\text { Demand multiplier }=\frac{100}{100-\mathrm{nrw}}
$$

Demand real = Kebutuhan air/SR x Deman multiplier

d. Perkiraan jumlah SR yang akan dilayani

$$
\text { jumlah } S R=\frac{\text { Q rencana }}{\text { Deman real }}
$$

\section{Perencanaan Sistem Jaringan Distribusi}

Perencanaan jaringan distribusi menggunakan aplikasi epanet dengan dasar asumsi dari daerah yang menjadi acuan, dengan kebutuhan debit 1,8 1/detik dan dengan jumlah sambungan SR sebanyak 140 . Kebutuhan air setiap SR akan digunakan untuk menghitung base demand per junction/node.

Kebutuhan air/SR $=\frac{\text { Jumlah pemakaian air }}{\text { Jumlah SR }}$

Data kebutuhan air ini kemudian digunakan untuk menentukan kebutuhan air dari setiap node atau blok yang ada di perumahan perencanaan. Gambar yang nantinya ditampilkan dalam epanet ini sendiri di antaranya:

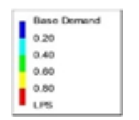

1.Bilik legenda berisikan informasi mengenai keterangan warna yang berkaitan dengan pipa dan node yang ada di sistem

2. Reservoir sebagai tempat penampungan air di suatu sistem jaringan

3. Pipa berfungsi sebagai penghubung antar node, media penyalur air

4. Node adalah titik pertemuan dari dua atau lebih elemen rangkaian, antara satu node dengan yang lain berisi keterangan jumlah rumah yang berbeda-beda

\section{Hasil dan Pembahasan}

\section{Perhitungan rata-rata jumlah penduduk}

Rata rata penambahan jumlah penduduk ini diambil dari data pada tahun pertama, kedua dan ketiga warga yang tinggal pada perumahan percontohan berdiri.

1) Persen jumlah penduduk pada tahun pertama sebagai Tabel 1.

Tabel 1. Data jumlah penduduk pada tahun pertama

\begin{tabular}{ccccc}
\hline & \multirow{2}{*}{$\begin{array}{c}\text { Nama } \\
\text { No. }\end{array}$} & Total & Jumlah & Tahun pertama \\
\cline { 4 - 5 } & Perumahan & rumah & $\begin{array}{c}\text { Jumduduk } \\
\text { pendun }\end{array}$ & Persen jumlah penduduk \\
\hline 1. & Rilis Permai & 24 & 63 & $65,6 \%$ \\
2. & Griya Kurnia 1 & 76 & 198 & $65,1 \%$ \\
3. & Griya Kurnia 2 & 96 & 257 & $66,9 \%$ \\
4. & Bhayangkara & 140 & 73 & $13,03 \%$ \\
5. & Ndalem Amalia & 39 & 64 & $41,02 \%$ \\
\hline \multicolumn{6}{l}{ Rata-rata persen jumlah penduduk } & $50,33 \%$ \\
\hline
\end{tabular}

Sumber: Data penelitian, 2020 
2). Persen jumlah penduduk pada tahun kedua, sebagai Tabel 2.

Tabel 2. Data jumlah penduduk pada tahun kedua

\begin{tabular}{clccc}
\hline & & & \multicolumn{2}{c}{ Tahun kedua } \\
\cline { 3 - 5 } No. & NamaPerumahan & Total rumah & Jumlah penduduk & $\begin{array}{c}\text { Persen jumlah } \\
\text { penduduk }\end{array}$ \\
\hline 1. & RilisPermai & 24 & 84 & $87,5 \%$ \\
2. & GriyaKurnia 1 & 76 & 221 & $72,7 \%$ \\
3. & GriyaKurnia 2 & 96 & 263 & $68,4 \%$ \\
4. & Bhayangkara & 140 & 301 & $53,75 \%$ \\
5. & NdalemAmalia & 39 & 49 & $31,4 \%$ \\
\hline \multicolumn{4}{c}{ Rata-rata persen jumlah penduduk } \\
\hline
\end{tabular}

Sumber: Data penelitian, 2020

3). Persen jumlah penduduk pada tahun ketiga, sebagai Tabel 3.

Tabel 3. Data jumlah penduduk pada tahun ketiga

\begin{tabular}{llccc}
\hline \multirow{2}{*}{ No. } & Nama Perumahan & Total & \multicolumn{2}{c}{ Tahun ketiga } \\
\cline { 3 - 4 } & rumah & $\begin{array}{c}\text { Jumlah } \\
\text { penduduk }\end{array}$ & $\begin{array}{c}\text { Persen jumlah } \\
\text { penduduk }\end{array}$ \\
\hline 1. & Rilis Permai & 24 & 67 & $69,8 \%$ \\
2. & Griya Kurnia 1 & 76 & 304 & $44,4 \%$ \\
3. & Griya Kurnia 2 & 96 & 183 & $47,6 \%$ \\
4. & Bhayangkara & 140 & 432 & $77,1 \%$ \\
5. & Ndalem Amalia & 39 & 84 & $53,8 \%$ \\
\hline \multicolumn{5}{c}{ Rata-rata persen jumlah penduduk } \\
\hline \multicolumn{5}{c}{ Sumber: Data penelitian, 2020 }
\end{tabular}

\section{Proyeksi Penduduk}

Hasil yang dapat dilihat dari metode least square, metode logaritmik dan metode eksponensial menunjukkan metode least square yang dipilih menjadi perhitungan untuk proyeksi penduduk karena menunjukkan nilai korelasi 0,85 yang paling mendekati nilai 1 [7].

Proyeksi penduduk Tahun 2024

Proyeksi penduduk tahun 2025

$$
\begin{aligned}
P n & =a+b x \\
& =498+41,5(3) \\
& =\underline{623 \text { jiwa }}
\end{aligned}
$$

$$
\begin{aligned}
P n & =a+b x \\
& =498+41,5(4) \\
& =\underline{664 \text { jiwa }}
\end{aligned}
$$

Dari perhitungan proyeksi penduduk selama 5 tahun, dapat dilihat pada Tabel 4.

\begin{tabular}{ccc}
\multicolumn{3}{c}{ Tabel 4. Proyeksi penduduk selama 5 tahun } \\
\hline Tahun & Cakupan & Jumlah penduduk \\
& $(\%)$ & (Jiwa) \\
2021 & 100 & 511 \\
2022 & 100 & 638 \\
2023 & 100 & 594 \\
2024 & 100 & 623 \\
2025 & 100 & 664 \\
\hline \multicolumn{3}{c}{ Sumber: Data penelitian, 2020}
\end{tabular}

\section{Data flow factor \& head factor}

\section{a. Flow factor}

Data pemakaian air menunjukkan pemakaian minimum terjadi pada pukul $01.00 \mathrm{WIB}$ dengan jumlah pemakaian air sebesar 1,4 liter/detik dan pemakaian tertinggi (jam puncak) terjadi dari pagi dan sore hari yaitu pukul 06.00-07.00 WIB dan 17.00-18.00 WIB yaitu sebesar 4,8 dan 4,2 liter/detik. 


\begin{tabular}{|c|c|c|c|c|c|}
\hline \multicolumn{6}{|c|}{ Tabel 5. Flow Factor } \\
\hline \multirow[b]{2}{*}{ No. } & \multirow{2}{*}{ Jam } & \multicolumn{2}{|c|}{ Kebutuhan air } & \multirow{2}{*}{$\begin{array}{c}\text { Rata- } \\
\text { rata } \\
\mathrm{L} / \mathrm{dt}\end{array}$} & \multirow{2}{*}{$\begin{array}{l}\text { Flow } \\
\text { factor }\end{array}$} \\
\hline & & $\mathrm{m}^{3} / \mathrm{jam}$ & $\mathrm{L} / \mathrm{dt}$ & & \\
\hline 1. & 1.00 & 5,04 & 1,4 & 3,21 & 0,43 \\
\hline 2. & 2.00 & 5,04 & 1,4 & 3,21 & 0,43 \\
\hline 3. & 3.00 & 5,4 & 1,5 & 3,21 & 0,46 \\
\hline 4. & 4.00 & 13,32 & 3,7 & 3,21 & 1,15 \\
\hline 5. & 5.00 & 16,2 & 4,5 & 3,21 & 1,4 \\
\hline 6. & 6.00 & 16,56 & 4,6 & 3,21 & 1,43 \\
\hline 7. & 7.00 & 17,28 & 4,8 & 3,21 & 1,55 \\
\hline 8. & 8.00 & 14,76 & 4,1 & 3,21 & 1,28 \\
\hline 9. & 9.00 & 12,96 & 3,6 & 3,21 & 1,12 \\
\hline 10. & 10.00 & 12,96 & 3,6 & 3,21 & 1,12 \\
\hline 11. & 11.00 & 12,6 & 3,5 & 3,21 & 1,1 \\
\hline 12. & 12.00 & 12,96 & 3,6 & 3,21 & 1,12 \\
\hline 13. & 13.00 & 10,44 & 2,9 & 3,21 & 0,9 \\
\hline 14. & 14.00 & 11,16 & 3,1 & 3,21 & 0,96 \\
\hline 15. & 15.00 & 11,16 & 3,1 & 3,21 & 0,96 \\
\hline 16. & 16.00 & 14,04 & 3,9 & 3,21 & 1,21 \\
\hline 17. & 17.00 & 14,76 & 4,1 & 3,21 & 1,28 \\
\hline 18. & 18.00 & 15,12 & 4,2 & 3,21 & 1,3 \\
\hline 19. & 19.00 & 14,4 & 4,0 & 3,21 & 1,24 \\
\hline 20. & 20.00 & 11,16 & 3,1 & 3,21 & 0,96 \\
\hline 21. & 21.00 & 10,44 & 2,9 & 3,21 & 0,9 \\
\hline 22. & 22.00 & 8,64 & 2,4 & 3,21 & 0,74 \\
\hline 23. & 23.00 & 5,4 & 1,5 & 3,21 & 0,46 \\
\hline 24. & 00.00 & 5,4 & 1,5 & 3,21 & 0,46 \\
\hline
\end{tabular}

\section{b. Head factor}

Head di dalam hasil penelitian ini berkaitan dengan ketinggian air dengan ketinggian daerah perencanaan, yang mana bisa dilihat dari head factor seperti pada Tabel 6.

Tabel 6. Head Factor

\begin{tabular}{ccccc}
\hline \multirow{4}{*}{ Jam } & \multicolumn{2}{c}{ Tekanan } & $\begin{array}{c}\text { Elevasi } \\
\text { mdpl }\end{array}$ & $\begin{array}{c}\text { Head } \\
\text { factor }\end{array}$ \\
\cline { 2 - 3 } & atm & meter & & \\
\hline 1.00 & 4,0 & 40 & 70 & 1,57 \\
2.00 & 4,0 & 40 & 70 & 1,57 \\
3.00 & 4,0 & 40 & 70 & 1,57 \\
4.00 & 3,6 & 36 & 70 & 1,51 \\
5.00 & 3,6 & 36 & 70 & 1,51 \\
6.00 & 2,4 & 24 & 70 & 1,34 \\
7.00 & 2,0 & 20 & 70 & 1,28 \\
8.00 & 1,6 & 16 & 70 & 1,22 \\
9.00 & 2,0 & 20 & 70 & 1,28 \\
10.00 & 2,4 & 24 & 70 & 1,34 \\
11.00 & 2,8 & 28 & 70 & 1,4 \\
12.00 & 2,6 & 26 & 70 & 1,37 \\
13.00 & 2,6 & 26 & 70 & 1,37 \\
14.00 & 3,2 & 32 & 70 & 1,46 \\
15.00 & 3,2 & 32 & 70 & 1,46 \\
16.00 & 3,0 & 30 & 70 & 1,42 \\
17.00 & 2,0 & 20 & 70 & 1,28 \\
18.00 & 2,0 & 20 & 70 & 1,28 \\
19.00 & 1,8 & 18 & 70 & 1,25 \\
20.00 & 2,4 & 24 & 70 & 1,34 \\
21.00 & 3,2 & 32 & 70 & 1,46 \\
22.00 & 3,6 & 36 & 70 & 1,51 \\
23.00 & 3,8 & 38 & 70 & 1,54 \\
00.00 & 3,8 & 38 & 70 & 1,54 \\
\hline & Sumber: Data penelitian, 2020 \\
\end{tabular}




\section{Kebutuhan air domestik dan non domestik}

Kebutuhan air maksimum rata-rata dari tahun 2021 sampai 2025 memiliki nilai sebesar 82.842,4 liter/hari atau jika dikonversikan menjadi 1,05 liter/detik. Sementara kebutuhan rata-rata dari tahun 2021 sampai tahun 2025 pada jam puncak sebesar 94.140 liter/hari atau jika dikonversikan menjadi 1,11 liter/detik sehingga dapat tercukupi dengan debit rencana 3,7 liter/detik. Kebutuhan air dapat dilihat pada Tabel 7.

Tabel 7. Kebutuhan air

\begin{tabular}{|c|c|c|c|c|c|c|}
\hline \multirow{2}{*}{ Uraian } & \multirow{2}{*}{ Satuan } & \multicolumn{5}{|c|}{ Tahun } \\
\hline & & 2021 & 2022 & 2023 & 2024 & 2025 \\
\hline Jumlah penduduk & Jiwa & 511 & 638 & 594 & 623 & 664 \\
\hline Cakupan pelayanan & $\%$ & 100 & 100 & 100 & 100 & 100 \\
\hline Konsumsi setiap orang & 1/orang/hr & 100 & 100 & 100 & 100 & 100 \\
\hline $\begin{array}{l}\text { Jumlah SR yang } \\
\text { dilayani }\end{array}$ & SR & 128 & 160 & 149 & 156 & 166 \\
\hline $\begin{array}{l}\text { Kebutuhan air } \\
\text { domestik }\end{array}$ & 1/hari & 51200 & 64000 & 59600 & 62400 & 66400 \\
\hline $\begin{array}{l}\text { Kebutuhan air non } \\
\text { domestik }\end{array}$ & 1/hari & 2040 & 2040 & 2040 & 2040 & 2040 \\
\hline Total kebutuhan & 1/hari & 53240 & 66040 & 61640 & 64440 & 68440 \\
\hline Kebocoran & $\%$ & 20 & 20 & 20 & 20 & 20 \\
\hline Kebutuhan+kebocoran & $1 /$ hari & 63888 & 79248 & 73968 & 77328 & 82128 \\
\hline Kebutuhan maksimum & 1/hari & 70276 & 87172 & 81364 & 85060 & 90340 \\
\hline $\begin{array}{l}\text { Rata-rata kebutuhan } \\
\text { maksimum }\end{array}$ & 1/hari & & & 82842,4 & & \\
\hline Kebutuhan jam puncak & 1/hari & 79860 & 99060 & 92460 & 96660 & 102660 \\
\hline Rata-rata jam puncak & 1/hari & & & 94140 & & \\
\hline
\end{tabular}

\section{Perencanaan Sistem Jaringan Distribusi}

Perencanaan jaringan distribusi menggunakan aplikasi epanet dengan dasar asumsi dari daerah yang menjadi acuan, dengan kebutuhan debit 1,8 1/detik dan dengan jumlah sambungan SR sebanyak 140 . Kebutuhan air setiap SR akan digunakan untuk menghitung base demand per junction/node, seperti Gambar 2 dan Gambar 3.

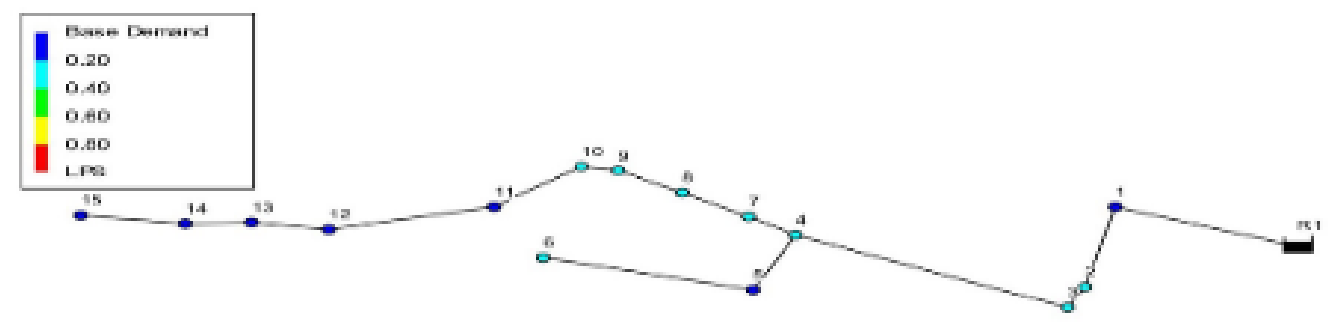

Gambar 2. Node berdasarkan base demand Sumber: Data penelitian, 2020

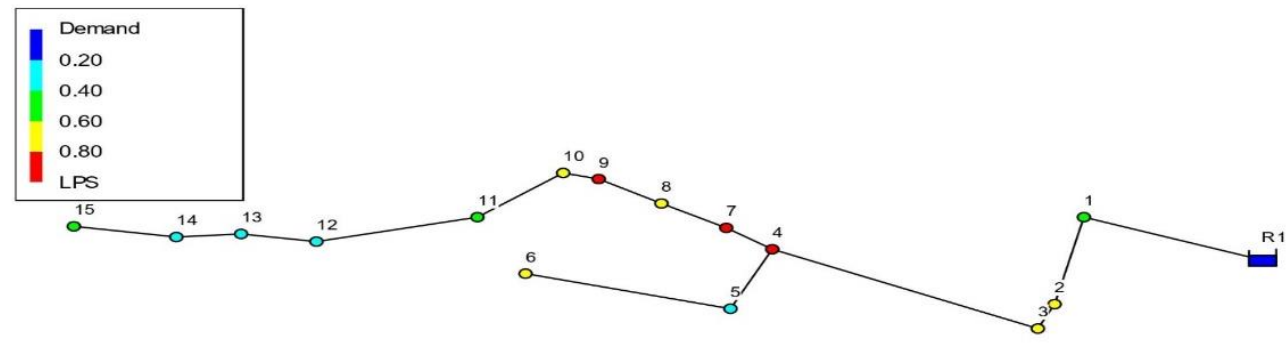

Gambar 3. Node berdasarkan demand Sumber: Data penelitian, 2020 
Dari Gambar 2 dan Gambar 3 yang dilengkapi dengan legenda yang mana penjelasannya untuk warna biru menunjukkan base demand $\leq 0,201 /$ detik, warna hijau muda $0,20<\mathrm{x} \leq 0,401 /$ detik, warna hijau $0,40<\mathrm{x} \leq 0,601 /$ detik, warna kuning $0,60<\mathrm{x} \leq 0,80 \mathrm{l} / \mathrm{detik}$, warna merah $0,801 /$ detik $\leq \mathrm{x}$. Node nomor 1 menunjukkan angka 0,192 liter/detik sehingga node menunjukkan warna biru dan seterusnya yang ditunjukkan pada Tabel 8 dan Tabel 9.

Tabel 8. Demand dan Base Demand domestik

\begin{tabular}{|c|c|c|c|}
\hline No. & Node & $\begin{array}{c}\text { Base demand } \\
(1 / \mathrm{det})\end{array}$ & $\begin{array}{c}\text { Demand } \\
(1 / \mathrm{det})\end{array}$ \\
\hline 1. & $\mathrm{~J} 1$ & 0,192 & 0,56 \\
\hline 2. & $\mathrm{~J} 2$ & 0,216 & 0,63 \\
\hline 3. & $\mathrm{~J} 3$ & 0,264 & 0,77 \\
\hline 4. & $\mathrm{~J} 4$ & 0,288 & 0,84 \\
\hline 5. & J5 & 0,132 & 0,38 \\
\hline 6. & J6 & 0,24 & 0,70 \\
\hline 7. & $\mathrm{~J} 7$ & 0,276 & 0,80 \\
\hline 8. & $\mathrm{~J} 8$ & 0,264 & 0,77 \\
\hline 10. & $\mathrm{~J} 10$ & 0,24 & 0,70 \\
\hline 11. & $\mathrm{~J} 11$ & 0,18 & 0,52 \\
\hline 12. & $\mathrm{~J} 12$ & 0,12 & 0,35 \\
\hline 13. & $\mathrm{~J} 13$ & 0,12 & 0,35 \\
\hline 14. & $\mathrm{~J} 14$ & 0,132 & 0,38 \\
\hline
\end{tabular}

Tabel 9. Demand dan Base Demand non domestik

\begin{tabular}{cccc}
\hline No & Node & $\begin{array}{c}\text { Base demand } \\
(1 / \text { det })\end{array}$ & Demand (1/det) \\
\hline 9 & J9 & 0,287 & 0,83 \\
15 & J15 & 0,1445 & 0,42 \\
\hline \multicolumn{4}{c}{ Sumber: Data penelitian, 2020}
\end{tabular}

\section{Flow dan velocity pada jam puncak di daerah perencanaan}

Pada Gambar 4 dilengkapi dengan legenda yang mana penjelasannya untuk pipa warna biru menunjukkan flow $\leq 4$ 1/detik, warna hijau muda $4<x \leq 8$ 1/detik, warna hijau $8<x \leq 12$ 1/detik, warna kuning $12<x \leq 161 /$ detik, warna merah $\leq 161 /$ detik. Sedangkan untuk legenda pipa di velocity menunjukkan nilai $\leq 0,01 \mathrm{l} /$ detik, warna hijau muda $0,01<x \leq 0,101 /$ detik, warna hijau $0,10<x \leq 1,001 /$ detik, warna kuning $1,00<x \leq 2,001 /$ detik, warna merah $21 /$ detik $\leq \mathrm{x}$.

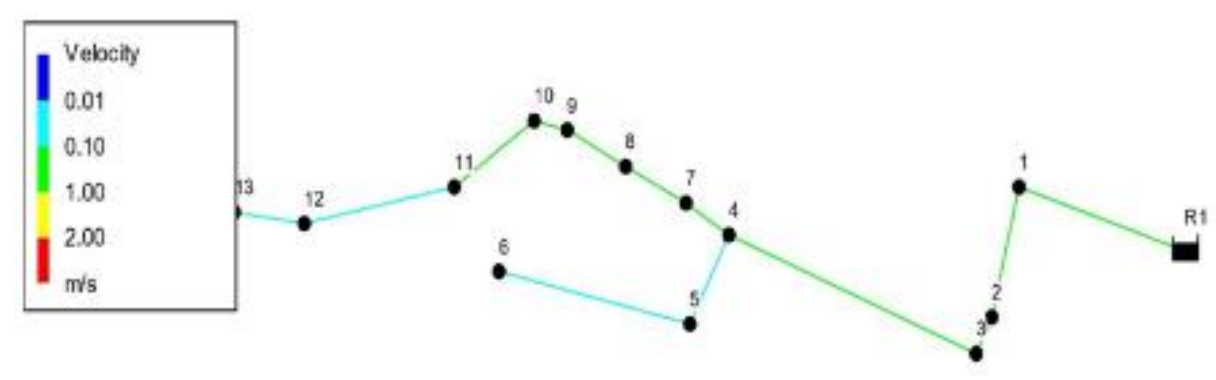

Gambar 4. Flow pada jam puncak Sumber: Data penelitian, 2020

Hasil dari simulasi epanet 2.0 dapat diketahui data kecepatan aliran (velocity) serta debit aliran (flow) pada jam puncak yaitu pada jam 06.00-07.00 WIB pada setiap junction. Jam puncak merupakan jam di saat 
kebutuhan air meningkat dikarenakan banyak orang yang sedang menggunakan air. Data velocity dan flow air ini dituliskan dapat dilihat pada Tabel 10.

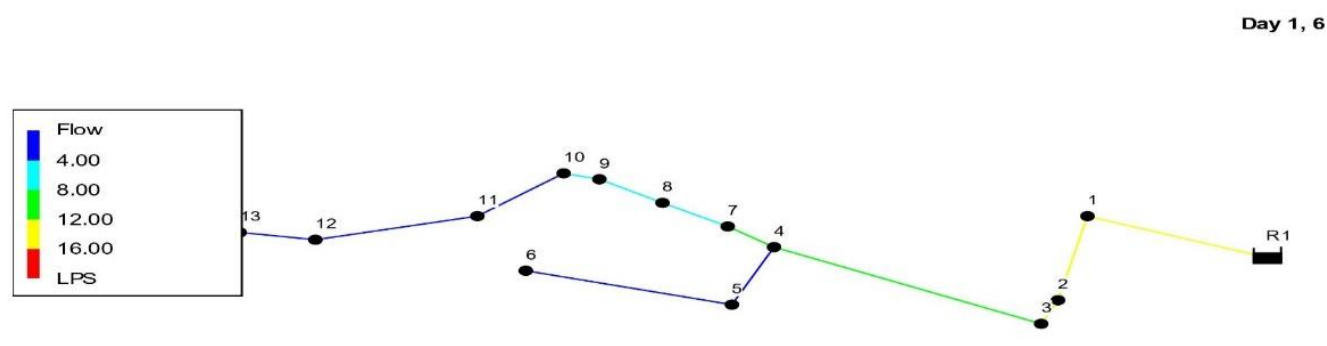

Gambar 5. Velocity pada jam puncak Sumber: Data penelitian, 2020

Tabel 10. Flow dan Velocity di perumahan perencanaan

\begin{tabular}{ccc}
\hline Pipa nomor & Flow (LPS) & Velocity $(\mathrm{m} / \mathrm{s})$ \\
\hline 1. & 14,86 & 1,89 \\
2. & 13,94 & 1,77 \\
3. & 12,90 & 1,64 \\
4. & 11,63 & 1,48 \\
5. & 1,79 & 0,23 \\
6. & 1,15 & 0,15 \\
7. & 8,46 & 1,08 \\
8. & 7,14 & 0,91 \\
9. & 5,87 & 0,75 \\
10. & 4,50 & 0,57 \\
11. & 3,34 & 0,43 \\
12. & 2,48 & 0,32 \\
13. & 1,90 & 0,24 \\
14. & 1,33 & 0,17 \\
15. & 0,69 & 0,09 \\
\hline
\end{tabular}

\section{Kesimpulan}

Berdasarkan analisis perhitungan dan simulasi epanet dalam perencanaan jaringan distribusi air bersih di perumahan yang akan dibangun di desa Logandeng kecamatan Playen kabupaten Gunungkidul, maka diperoleh kebutuhan air sebesar 1,118 1/detik yang mampu memenuhi sebanyak 664 jiwa dengan kecepatan aliran paling tinggi pada saat jam puncak di pipa nomor 1 dengan kecepatan 1,89 m/s, sedangkan untuk kecepatan terendah di jam puncak terjadi pada pipa nomor 15 yaitu sebesar $0,09 \mathrm{~m} / \mathrm{s}$. Debit aliran dalam pipa paling tinggi pada jam puncak terdapat di pipa nomor 1 sebesar 14,86 liter/detik, sedangkan untuk debit terendah pada jam puncak terletak pada pipa nomor 15 yaitu sebesar 0,69 liter/detik. Pada perencanaan sistem jaringan pipa distribusi menggunakan sistem pengaliran secara gravitasi dan menggunakan sistem bercabang.

\section{Saran}

Sistem jaringan distribusi agar berjalan dengan baik dan aman secara keseluruhan terdapat beberapa saran yang perlu diperhatikan, yaitu selalu diadakan pengambilan data penduduk secara rutin setiap tahun, karena warga di daerah perumahan tidak selamanya menetap. Dalam pengoperasiannya dianjurkan untuk selalu memeriksa keadaan pipa secara rutin, karena untuk menghindari adanya kerusakan pipa, juga perlu adanya pengecekan kebocoran secara berkala, guna meminimalisir terjadinya kerugian pada pengguna dan PDAM Tirta Handayani Gunungkidul.

\section{Daftar Pustaka}

[1] Adil, A., Sistem Informasi Geografis, Penerbit Andi, Yogyakarta, 2017

[2] Armanto, R.N., dan Indarjanto,H., "Analisis dan Perencanaan Pengembangan Sistem Air Minum di PDAM Unit Plosowahyu Kabupaten Lamongan”, Jurnal Teknik ITS Vol. 5, No. 2, pp 247-252, 2016 
[3] Badan Pengembangan Sumber Daya Manusia Kementrian Pekerjaan Umum dan Perumahan Rakyat, Perencanaan Jaringan Pipa Transmisi dan Distribusi Air Minum, 2018

[4] Bappeda Kabupaten Kulon Progo, Rencana Induk Sistem Penyediaan Air Minum (RISPAM) Kabupaten Kulon Progo. Wates: Pemerintah Daerah Kabupaten Kulon Progo, 2014

[5] Bhaskoro, R.G.E dan Ramadhan T, "Evaluasi Kinerja Instalasi Pengolahan Air Minum (IPAM) Karangpilang I PDAM Surya Sembada Kota Surabaya Secara Kuantitatif”, Jurnal Presipitasi: Media Komunikasi dan Pengembangan Teknik Lingkungan Volume 15 Nomor 2 Akademi Teknik Tirta Wiyata Magelang, Magelang,62-68, 2018

[6] Diana,E.W., Sholichin, M., Haribowo, R., "Kajian Pengembangan Jaringan Distribusi Air Bersih pada PDAM Tirta Barito Kota Buntok", Jurnal Teknik Pengairan,vol 8 (1), pp 8-17, 2020

[7] Erwin, F., Azmeri, Fatimah, E., "Faktor Dominan dan Strategi Penyedian Air Bersih di Desa Rawan Air Bersih Pada Kecamatan Baitussalam Kabupaten Aceh Besar", Jurnal Teknik Sipil Volume 1 Special Issue Nomor 4,Universitas Syiah Kuala, Aceh, pp 903-914, 2018

[8] Kalensun, H., Kawet,L., Halim, F.,"Perencanaan Sistem Jaringan Distribusi Air Bersih Di Kelurahan Pangolombian Kecamatan Tomohon Selatan", Jurnal Sipil Statik, pp 105-115, 2016

[9] Martheana, K., Mustakim,H., Ramdhan,M., "Analisis Distribusi Air Bersih Berdasarkan Parameter Debit dan Tekanan Air", Jurnal Transukma Volume 02 Nomor 01, Universitas Balikpapan, Kalimatan Timur, pp 1-6, 2016

[10] Nugroho, S., Meicahayanti, I.., dan Nordiana, Y., "Analisa Jaringan Perpipaan Distribusi Air Bersih Menggunakan EPANET 2.0 (Studi Kasus di Kelurahan Harapan Baru, Kota Samarinda)", Jurnal Teknik, vol 39 (1), Universitas Mulawarman, Samarinda, pp 62-66, 2018

[11] Peraturan Menteri Kesehatan Republik Indonesia No.492/MENKES/PER/IV/2010 Tentang Persyaratan Kualitas Air Minum

[12] Peraturan Pemerintah (PP) No. 122 Tahun 2015 tentang Sistem Penyediaan Air Minum

[13] Riduan, R., Firmansyah, M., Fadhilah,S., "Evaluasi Tekanan Jaringan Distribusi Zona Air Minum Prima (ZAMP) PDAM Intan Banjar Menggunakan Epanet 2.0", Jurnal Teknik Lingkungan (Jukung) Volume 3 Nomor 1 Universitas Lambung Mangkurat, Kalimantan Selatan, pp 12-20, 2017

[14] Sihombing, A.T., "Analisis Kinerja Sistem Distribusi Air Bersih PDAM Tirta Silaupiasa Kabubaten Asahan", Jurnal Pionir LPPM Volume 5 Nomor 2 Universitas Asahan, Sumatera Utara, pp 1-10, 2019

[15] Suustra A., Kartini,Nirmala, A., "Perencanaan Pengembangan Sistem Jaringan Distribusi Air Bersih di Kecamatan Sungai Kakap Kabupaten Kubu Raya", JeLAST, vol 5 no 2,1-5, 2018

[16] Tambingon, D.P., Hendratta, L.A., Sumarauw, J.S.F., "Perencanaan Pengembangan Sistem Distribusi Air Bersih di Desa Pakuure Tinanian”, Jurnal Sipil Statik Vol.4 No.9, pp 541-550, 2017 